\title{
4 \\ The Sources of Confusion over Social and Territorial Organisation in Western Victoria
}

\author{
Raymond Madden
}

\section{Introduction}

This chapter looks at the present-day confusion surrounding the relationship between territorial and social organisation in the western Victoria region, and assesses the impact of this confusion on the anthropological modelling of social and territorial changes over time. This chapter also discusses the possible causes and consequences of misrecognition in the written and oral records in relation to the original Aboriginal land tenure in western Victoria. Simply put, the issue that arises is that some contemporary sources suggest that there is matrilineal descent at the local level in the original western Victorian Aboriginal societies. However, there is no credible evidence for matrilineal descent at the local level, but there is credible evidence for patrifilial local estate groups. How did this situation arise? There are a number of published amateur ethnographic and social-geographic accounts of Aboriginal social and territorial organisation in western Victoria that span from the mid-1800s to the early 1900s. Of particular importance are the works of G. A. Robinson (in Clark 1998a-c, 2000), J. Dawson (1881), A. W. Howitt (1996 [1904]), R. B. Smyth (1876), J. Mathew (1911) and R. H. Mathews (1904). While these accounts are useful reconstructive 
sources, the ethnographic portrait of the contact period in western Victoria remains relatively patchy. Further, there is a complicating factor in the task of reconstruction in that some contemporary reconstructions have misinterpreted key aspects of these early works. For example, the works of Dawson (1881) and Howitt (1996 [1904]) contain information about the matrimoiety social organisation that was found across the region, and the manner in which this information and these systems have been misunderstood has had an impact on the present-day understandings in Aboriginal and research communities of the original territorial and social systems.

\section{Study Area}

The study area (see Figure 14) roughly covers the south-western corner and central western area of the state of Victoria. This corresponds with areas commonly referred to as the Western District, south-west Victoria, the Grampians and the southern Wimmera.

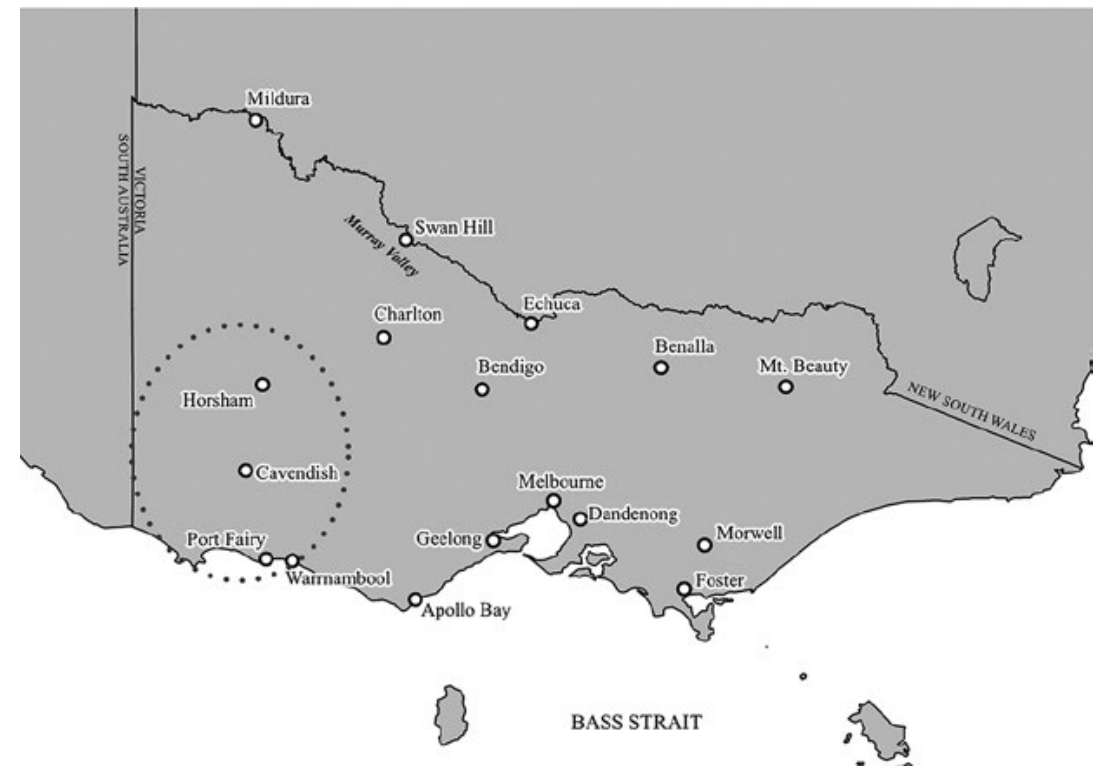

Figure 14: Study area.

Source: Editors' work. 


\section{Language and Nomenclature}

Three macrolanguages were found across the study area. In a small portion of the extreme west of the study area, the Buganditj ${ }^{1}$ macrolanguage was present (Blake \& Reid 1998, p. 58; Clark 1990, pp. 411-13); however, I will not be dealing with this group in this chapter, other than to note that the information later presented on territorial and social organisation equally applies to the Buganditj as it does to the other groups in the study area. The Maar or 'Warrnambool' macrolanguage was found on the southwest coast and hinterland region (Blake \& Reid 1998, p. 58) and includes the dialects of Wullu wurrung, Dhauwurd wurrung, Gai wurrung, Gurngubanud, Big wurrung, Girrae wurrung, Wirngilgnad dalinanong, Djargurd wurrung, Gadubanud (Clark 1990) and Kirrim kirrim wurrung (Dawson n.d.). The Grampians, Wimmera and Mallee regions were covered by the dialects of the large 'western Victorian' macrolanguage (Blake \& Reid 1998, p. 58) that includes the dialects of Djab wurrung, Pirtpirt wurrung, Knenknen wurrung, Nundajali, Mardidjali, Jardwadjali, Jagwadjali, Djadjala, Buibadjali, Biwadjali and Wudjubalug (Clark 1990). ${ }^{2}$ Original accounts and more recent reconstructions of groups in the study area leave us with a range of nomenclature for the original inhabitants, based on attempts to reconstruct and name differing levels of human organisation (social, territorial, linguistic, geographic and cultural). When referring directly to particular works, I will use the terms as presented in those texts; however, in more general discussion, I will interpolate in order to simplify this nomenclatural landscape. I will refer to the two macrolanguage groups in the study area by reference to the dominant term for 'person' or 'persons'. In the southern section of the study area, the dominant term for person is 'Maar'; in the mid and northern reaches of the study area, the common term for people is 'Guli'. It is the Maar and Guli macrolanguage groups that are the focus of this chapter. The Maar and Guli macrolanguages share a matrimoiety social organisation and the apical totems of this system are referred to in cognate terms: Kuurokeetch and Kappatch for the Maar (Dawson 1881), and Krokitch and Gamutch for the Guli (Howitt 1996 [1904]). For simplicity, in general discussion, I will refer to this overarching social organisation as the Krokitch/Gamutch system (after Howitt 1996 [1904]).

1 Alternatively referred to as the Booandik (Stewart 1880), Buganditch (Tindale 1974) or Buandig (Clark 1990).

2 Clark (1990) divided this area into two large related languages that he labelled Jardwadjali and Wergaia; Blake and Reid (1998, p. 58) referred to those areas as the Grampians and Wimmera languages respectively. 


\section{Key Early Sources}

While there are a number of early ethnohistoric sources for the study area, the questions being posed in this chapter can be worked through adequately with primary reference to two key early sources: Dawson (1881) and Howitt (1996 [1904]). The works of Dawson (1881) and Howitt (1996 [1904]) were in large part an attempt to present a picture of the customs, beliefs and organisation of the Aboriginal population at the point of the arrival of the Europeans. This task was undertaken via the use of Aboriginal informants-usually people who had memories of times before European arrival-and Dawson and Howitt also sought information from other settlers, colonial authorities and mission authorities. In relation to the study area, Dawson (1881, p. iii) and Howitt (1996 [1904], p. x) both had personal contacts with informants from the region and did not need to rely on second-hand accounts.

\section{Dawson (1881)}

Dawson lived in the study area from 1844 until his death in 1900 . During this time, he formed close and abiding relationships with the local Aboriginal people, such that he was appointed the Local Guardian of Aborigines. He assisted his daughter Isabella in recording the customs and cultures of various Maar and Guli dialect groups with which he came into contact in western Victoria, and they published their research in 1881 in The Australian Aborigines: The Languages and Customs of Several Tribes in the Western District of Victoria, Australia (for more on Dawson's life in western Victoria, see Madden 2006, 2010). Dawson's Australian Aborigines remains one of the more useful ethnographic records of the first few decades of the post-contact period in western Victoria. Dawson's work assists in clarifying some of the misrepresentations related to social and territorial organisation in the study area. However, it is by no means a comprehensive resolution to all the questions that cohere around this matter, as Dawson's work also contains confusing information that may have contributed to some of the problematic issues being examined in this chapter.

Australian Aborigines is divided into 23 short chapters that cover subjects such as tribes, property, population, marriage and chiefs; matters such as mortuary practices and beliefs, regional meetings and dispute resolution; and broader Indigenous knowledge system information, such as 
astrological and meteorological knowledge. The work contains a series of tabulated vocabularies in the Chaap wuurong ('broad lip'), Kuurn kopan noot ('small lip') and Peek whuurong ('kelp lip') dialects of south-west Victoria that present lists of general words for each dialect, as well as lists of quadrupeds, birds, reptiles, fishes and crustacea, insects, relationship terms and placenames. Dawson's vocabularies are important in respect to the level of detail they provide on the biosphere and toponymy of the area before colonisation. There is also a section on grammar and sentences, numbers and counting, and a series of short notes-with some in Latin (referring to 'delicate' matters of sexual relations and bodily functions).

Dawson wrote about a number of forms of Aboriginal territorial and social organisation in western Victoria. He described 'families' who held titles to small estates, tribes who were presided over by a chief (Dawson 1881, p. 7), languages into which various tribes were allocated (pp. 2-3) and the 'marriage classes' (pp. 26-37) that occurred across southern parts of the study area. In his writing, Dawson made little of the differences between the larger Maar and Guli language groupings, and he typically wrote about the south-west of Victoria as if it were a large culture bloc.

\section{Howitt (1996 [1904])}

Howitt's published writings and manuscript notes cover the latter decades of the nineteenth century and the early part of the twentieth century (1884, $1886,1888,1904)$. His informants were people who had memories of the time when Europeans first arrived in Victoria (or were told of such times by their parents or grandparents). Howitt's work is significant because he personally spoke with Aboriginal people who originated from the northern reaches of the study area (specifically Wotjobaluk, Muckjarawaint and Jupagalk people). Howitt's major work The Native Tribes of South-East Australia (1904) is a sprawling tome in excess of 800 pages that collates much of his work across the previous decades and provides information on social, territorial and linguistic organisation across south-east Australia (including the study area). The chapters cover themes such as origins, tribal organisation, social organisation, marriage rules, tribal government and medicine men. This work is thematically typical of the evolutionistcum-comparative amateur ethnographies that were being produced towards the end of the nineteenth and into the early twentieth century. While Howitt was abundantly aware of the relationship between social and territorial organisation in the original societies of western Victoria, 
his typology was rather unorthodox. Subsequently, Howitt's work provides some clues as to the possible sources of later confusion regarding local organisation in the study area.

\section{Territorial Organisation}

According to Dawson (1881, p. 7), local territory was handed down in a patrifilial fashion (although adoption and birthplace could also confer membership of a local estate group) and each person belonged to the 'tribe' of their father. Dawson's 'tribe' generally corresponds with the contemporary understanding of the dialect group. Dawson (1881, p. 7) compartmentalised his 'tribe' by introducing the concept of the territorial 'family'. This 'family' seems to correspond in large part to the present-day understanding of a small local estate group; for example:

The territory belongs to the tribe and is divided among its members. Each family has the exclusive right by inheritance to a part of the tribal lands, which is named after its owner; and his family and every child born on it must be named after something on the property. (Dawson 1881, p. 7; emphasis added)

Dawson went on to add some confusing detail regarding the distribution of a deceased estate, which will be discussed later in this chapter. While these viri-patrilocal (Dawson 1881, pp. 27, 31) and patrifilial 'families' are associated with particularly well defined tracts of country, they did move off their countries for feasts and ceremonial business associated with seasonally abundant food resources. These feasts have been recorded in a number of sources (Coutts 1981, p. vii; Dawson 1881, pp. 3, 78). However, unsanctioned movement (i.e. trespass) was severely punished, as in other areas of Aboriginal Australia (Dawson 1881, p. 7).

In The Native Tribes of South-East Australia (1904, p. 41), Howitt discussed 'tribes' and 'nations':

I use the word 'tribe' as meaning a number of people who occupy a definite tract of country, who recognise a common relationship and have a common speech or dialects of the same. The tribes-people recognise some common bond which may be their word for 'man', that is, an Aboriginal of Australia ... But while individual tribes are thus distinguished from others, there are numerous cases in which the word for 'man' is common to the languages of a considerable number of more or less nearly related tribes, indicating a larger aggregate, for which, in default of a better term, I use the word 'nation'. 
Howitt also specified a third level, the 'horde' or 'clan', which is recognisable as a local estate group:

In order to make clear the definition of the terms I use, the following is given:-

1. Nation is used to signify a group of tribes.

2. Tribe is used in the sense given at p. 41 [i.e. people who occupy a definite tract of country and recognise a common relationship].

3. Horde, the primary geographical division of a tribe having female descent ...

4. Clan, the primary geographical division of a tribe with descent in the male line ... (Howitt 1996 [1904], p. 44)

Here, Howitt uses 'horde' to stand for a local group that has a matrimoiety social organisation and 'clan' for a local group that has a patrimoiety social organisation. Similarly to Dawson, this is a complex piece of information that will be discussed later in this chapter. However, what is evident is that in referring to the 'hordes' of the matrimoiety societies (as in the study area), Howitt (1996 [1904], p. 43) was clear that they were patrifilial and the descent he wrote of referred only to social organisation.

\section{Social Organisation}

Some early ethnohistoric sources confused or misread information related to social organisation in the study area (see Mathews 1904). For example, while G. A. Robinson was useful in documenting local levels of organisation, he was seemingly unaware of the overlaying social organisation of the people he moved among. In one instance, after recording the details of a man from the 'Cole.ler.cone.deet' (Color gunditj) group, upon whom he had conferred the name 'Pompey', he wrote:

Cur.er.quite, alias Pompey, conferred by me, country Weeng.burn, at Conenewurt, W. by N. from Kilambete, a 1. Cole.ler.cone.deet, 2. Wen. ne.cood.it.bar. (cited in Clark 2000, p. 69)

'Cur.er.quite' is almost certainly a rendering of 'Kurrokeetch' (after Dawson 1881), one of the matrimoieties found across the study area, and not a 'personal' name that could be seen as an alias for Robinson's conferred name. Still, Dawson and Howitt appreciated the social organisation of the groups that they wrote about. For example, Dawson (1881, p. 26) wrote: 
Each person is considered to belong to his father's tribe and cannot marry into it. Besides this division there is another which is made solely for the purposes of preventing marriage between maternal relatives. The Aborigines are everywhere [in western Victoria] divided into classes; and everyone is considered to belong to his mother's class, and cannot marry into it in any tribe, as all of the same class are considered brothers and sisters. (emphasis in original)

Dawson's informants told him there were five 'marriage classes' in the southern part of the study area and that they originated from two key ancestors-the 'long-billed cockatoo' (long-billed corella, Cacatua tenuirostris) and the 'banksian cockatoo' (red-tailed black cockatoo, Calyptorhynchus magnificus):

The kuukuur minjer, or first great great grandfather, was by descent a kuurokeetch, long-billed cockatoo, but whence he came no one knows. He had for a wife a kappaheear, banksian cockatoo. She is called the kuurappa moel, meaning first great great grandmother. This original pair had sons and daughters, who, of course, belonged to the class of their mother ... As the laws of consanguinity forbade marriages between these it was necessary to introduce wambepan tuuram 'fresh flesh' which could only be obtained by marriage with strangers. The sons got wives from a distance ... and thus the pelican, snake, and quail classes were introduced. (Dawson 1881, p. 27)

There are five classes in all the tribes of the Western District, and these take their names from certain animals - the long billed cockatoo, kuurokeetch; the pelican, kartpoerapp; the banksian cockatoo, kappatch; the boa snake, Kirtuuk; and the quail, kuunamit. According to their classes the aborigines are distinguished as-

Kuurokeetch, male; kuurokaheear, female.

Kartpoerapp, male; kartpoerapp hear, female.

Kappatch, male; kappaheear, female.

Kirtuuk, male; kirtuuk hear, female.

Kuunamit, male; kuunamit hear, female.

Kuurokeetch and kartpoerapp, however, are so related, that they are looked upon as sister classes, and no marriage between them is permitted. It is the same between kappatch and kirtuuk; but as kuunamit is not so related, it can marry into any class but its own. (Dawson 1881, p. 26)

Putting aside the Kuunamit or 'quail' class, these quotations show four non-localised matriclans or matriphratries arranged in 'sister' couplets and operating as a variation of a typical matrimoiety system (see also Howitt 
1996 [1904], p. 125, who records these same 'sister' couplets in the study area, but not the fifth 'quail' group). ${ }^{3}$ While there is no unequivocal evidence to suggest that there are any preferential marriage arrangements between the matriclans of the Kuurokeetch/Kartpoerapp and Kappatch/ Kirtuuk moieties, it is tempting to see here the initial stages of a shift from a moiety system to a section system. However, in addition to the origin story, the claim that a typical moiety system underpinned the social organisation of south-west Victoria is supported by the fact that its function was not restricted to regulating marriage, but rather the system was implicated in an ordering of the material, spiritual and cosmological dimensions of life. In this way, all matter and phenomena were said to belong to one moiety or the other. An elegant example of this basic dual structure is given by Dawson (1881, p. ix) when he relayed how his Aboriginal informants described the purple and blue arches of crepuscular light at sunset as 'white cockatoo' and 'black cockatoo' twilight respectively.

Howitt (1996 [1904], pp. 88-9) referred to moieties as 'classes' and saw them as the basic unit of Aboriginal social organisation across Australia. In The Native Tribes of South-East Australia, Howitt (1996 [1904], p. 42) stated:

In all the native tribes of Australia there are geographical divisions of the community determined by locality, and also divisions of the tribe on which the marriage regulations are based. The former are distinguished by certain local names, while the latter are denoted by class names, or totems, and more frequently by both class names and totems.

In the aggregate of the community these two sets are coterminous, but under female descent no division of the one set is coterminous with the other. That is to say, the people of any given locality are not all of the same class or totem, nor are the people of any one class or totem collected in the same locality.

Here, then, is evidence that Howitt grasped how social organisation overlaid and intermeshed with territorial organisation. He grasped how non-localised matriclans were distributed generally among the patrifilial estate groups and in relation to the study area. This was the point at which Mathews (1904, p. 289) attempted to associate tracts of country with these non-localised social matriclans of the Wimmera, and we will return

3 While the 'floating' class of Kunnamit or 'quail' might be an anomaly at present, we would do well to heed the advice of Lévi-Strauss (1979, pp. 161-2) on the subject of dual organisation to constantly be on the lookout for a dialectical or third force that complicates apparent simple binaries. 
to this point later in a discussion on the work of Clark (1990). In writing about the Guli, who were associated with the mid and northern reaches of the study area, Howitt generally used examples of the Wotjobaluk as indicative of the social organisation of the region. He proposed that the Wotjobaluk matrimoiety system was 'anomalous' due to the fact that some of the 'totems [had] advanced almost to the grade of sub-classes, and they [had] a markedly independent existence' (Howitt 1996 [1904], p. 122). He noted that the system of 'class names, totems, and sub-totems [were] called mir' (Howitt 1996 [1904], p. 122). A quick distillation of Howitt's schema is illustrated in Table 5 (my interpretation of Howitt's labels is indicated in square brackets).

Table 5: 'Wotjobaluk Tribe'.

\begin{tabular}{|l|l|l|}
\hline $\begin{array}{l}\text { 'Classes' } \\
\text { [matrimoiety] }\end{array}$ & $\begin{array}{l}\text { 'Totems' } \\
\text { [social matriclans] }\end{array}$ & $\begin{array}{l}\text { 'Sub-totems' } \\
\text { [matrifilial totems] }\end{array}$ \\
\hline 'Gamutch' & $\begin{array}{l}\text { 'Jalan-deaf adder' } \\
\text { 'Ngungul-the sea' } \\
\text { 'Batya-ngal-pelican' } \\
\text { 'Wurant-black cockatoo' }\end{array}$ & \\
\hline [24 totems listed] \\
& $\begin{array}{l}\text { 'Ngaui-the sun' } \\
\text { 'Garchuka-galah cockatoo' } \\
\text { 'Barewun-a cave' } \\
\text { 'Batya-ngal-pelican' } \\
\text { 'Moiwilluli-carpet snake' } \\
\text { 'Wartwut-the hot wind' } \\
\text { 'Munya-a tuber' }\end{array}$ & [19 totems listed] \\
\hline
\end{tabular}

Source: Adapted from Howitt (1996 [1904], p. 121).

Howitt (1996 [1904], p. 123) suggested that people were said to 'belong to' or were 'owned' by their 'class' and 'totem', but they 'owned' their 'sub-totem', perhaps hinting at a parent-sibling-child hierarchy in this class-totem-sub-totem arrangement. However, Howitt (1996 [1904], pp. 122-3) also admitted that his data on social organisation were incomplete, especially as they related to the mortuary totems of this system. Nevertheless, he was able to ascertain that each individual after death was also given a mortuary totem based on their living associations. One of Howitt's (1996 [1904], p. 123) informants 'was Krokitch-ngaui. When he died, he would become Wurti-ngaui, which means "behind the sun", or a shadow cast behind the speaker by the sun'.

Further, while Howitt saw the matriclans as having a 'markedly independent existence', he provided no certain data on preferential marriage between the matriclans. As such, despite Howitt's views on this system being 
'anomalous' (due to its primary-secondary-tertiary totemic hierarchy), it effectively functioned as a typical matrimoiety system, arranging both the conduct of marriage and all matter and phenomena in a dualistic cosmological order.

In Table 6, the 'equations' formulate the western Victorian matrimoiety marriage systems as presented in Dawson (1880) and Howitt (1996 [1904]), and compare them with a typical section system.

Table 6: Western Victorian matrimoiety marriage systems as presented in Dawson (1880) and Howitt (1996 [1904]), compared with a typical section system.

\begin{tabular}{|l|l|l|}
\hline $\begin{array}{l}\text { Howitt's Wotjobaluk } \\
\text { matrimoiety system: }\end{array}$ & $\begin{array}{l}\text { Dawson's matrimoiety system, } \\
\text { with its five 'matriphratries': }\end{array}$ & $\begin{array}{l}\text { A typical section } \\
\text { system }\end{array}$ \\
A (Krokitch); B (Gamutch) & $\begin{array}{l}\text { A (Kuurokeetch); B (Kappatch); } \\
\text { C (Kartpoerapp); } D \text { (Kirtuuk); }\end{array}$ & \\
& $\begin{array}{l}\text { E (the 'floating' matriclan, } \\
\text { Kuunamit) }\end{array}$ & \\
\hline$A=b \rightarrow B / b$ & $A / C=b / d \rightarrow B / b / D / d$ & $A / a=B / b \rightarrow C / c=$ \\
$a=B \rightarrow A / a$ & D/d $=B / D \rightarrow A / d / C / c$ & $A / a$ \\
& $E=a / b / c / d \rightarrow A / a / B / b / C / c / D / d$ & \\
& $e=A / B / C / D \rightarrow E / e$ & \\
\hline
\end{tabular}

Note: Uppercase is 'male'; lowercase is 'female'; = is 'marriage'; $\rightarrow$ is 'descent'; / is 'or'. Source: Adapted from Dawson (1880) and Howitt (1996 [1904]).

To summarise the points on the original forms of organisation, we can state that the study area was predominantly covered by two macrolanguages that, among a range of grammatical and lexical differences, possessed distinct words for 'Aboriginal person(s)'-Maar and Guli. These people were otherwise closely related in social and cultural terms. The macrolanguages were composed of dialect groups that have typically been referred to as 'tribes' in the early literature. Membership of the 'tribe' was patrifilial, and accordingly one got one's language from one's father. The land of the study area was occupied by numerous local estate groups who were patrifilial and viri-patrilocal in organisation. In addition, there were matrimoieties (and/or matriphratries) over the whole of the study area. These matrimoieties were essentially variations of the Krokitch/ Gamutch (white cockatoo/black cockatoo) system outlined by Howitt (1996 [1904]). 


\section{Colonisation and Social Change}

In the intervening years since the violent colonisation of the study area, a number of crucial social changes have occurred in the resident Aboriginal communities, and a quick sketch of these changes will assist in the discussion of present-day confusion around social and territorial organisation. The colonisation of western Victoria has been noted as a particularly violent encounter (Clark 1990, 1995; Critchett 1982, $1990,1992,1998)$. In the first two decades of colonisation, it is estimated that violence, disease and starvation resulted in a population loss of up to 80 per cent in some areas (Clark 1990, p. 53). Correspondingly, there was a loss of language across the area and by July 1880 , Dawson (1881, p. 4) was only able to list 14 people who spoke the three local dialects referred to in his text. This population shock and subsequent sedentarisation of the surviving people on missions or reserves also dealt a blow to territorial and social organisation; there were neither the numbers of people nor the freedom of movement to maintain the matrimoieties and original patrifilial estate groups. The surviving local groups quickly began a process of merging and/or collapsing into larger regional territorial domains, as contiguous estate groups were rendered extinct (see Clark 2006). In the decades after the invasive phase of colonisation, the now sedentarised 'mission'-based mobs formed collective identities based on their shared residential attachments and common connections (ancestral and cultural) to the original groups that felt the full force of colonisation. Over time, the old patrifilial estates succeeded into regional cognatic super estates, and there has been a corresponding decline of significance of patrilineal descent and an amplification of cognatic descent. With the loss of moiety systems, there was instead an emphasis on a general rule of family exogamy. This stress on family exogamy fed into an increased depth of descent reckoning, as an effect of education and literacy. Indeed, it is common knowledge that these extended Aboriginal families will have one or more particularly knowledgeable Aunties who can recite genealogies going back as far as seven generations. Finally, over time, there has been a shift towards a more matrifocal family structure (Keen 1988, pp. 12-13), including the increased public status of senior women. These changes are common to many Aboriginal communities that have had a long exposure to colonial forces, and this shift approximates those that have been outlined by Sutton (2003, pp. 206-31) in his discussion of 'post-classical families of polity' and the cognatic shift. 


\section{Contemporary Issues: Clark (1990)}

I have heard Aboriginal people making statements about their ancestral groups that can be paraphrased as: 'we were matrilineal down here in the Western District'. These comments were not necessarily focused on territorial or social organisation specifically, but were general statements about an overarching organisational principal that existed in the past and continues to influence a sense of group and self today. This is as if to say, their communities were, and continue to be, in essence matrilineal. While there is no doubt that a number of factors feed into this contemporary reckoning-such as the tendency towards matrifocal residence and perhaps a general investment in a 'mother earth' philosophy (see Swain 1991) — published sources may have also played a part in the production of this ideology of matrilineality.

In particular, I am referring to social geographer, Ian D. Clark's Aboriginal Languages and Clans: An Historical Atlas of Western and Central Victoria, 1800-1900 (1990). This text is a significant reconstructive project that has collated and analysed much of the early ethnohistoric records related to the Aboriginal groups of western and central Victoria. Drawing on a wide range of sources, and in particular the information in G. A. Robinson's 1840s journals, Clark undertook the ambitious and worthy task of plotting, as best as he could with the available information, the locations of recorded local estate groups. However, Clark made one consistent anthropological error in relation to the Maar and Guli of the study area, and that was to conclude that western Victorian groups with matrimoieties also had local territorial 'clans' that were matrilineal. ${ }^{4}$ Clark (1990, p. 28), who used the term 'clan' for local estate group, said of the Dhauwurd wurrung (south-west Victoria):

Clan and moiety affiliation was matrilineal and clans were either Krokitch ... or Kappatch ... However, it is impossible to identify which clans belonged to which moiety because of a lack of detailed information on ... marriages.

This statement on local organisation is of course contrary to the data presented in Dawson (1881) and Howitt (1996 [1904]), and this is not an isolated example. In at least five other instances, Clark (1990, pp. 80,

4 In one instance, Lydon (2009, p. 41) made this same error in relation to the 'Wergaia' of the northern parts of the study area. 
$91,222,237,339)$ suggested that local groups in matrimoiety systems were matrilineal. For example, Clark (1990, p. 80) observed of the ' $(\mathrm{Ng})$ Ure gundidj' clan:

In 1841 this clan had been reduced to one old man $\ldots$ and his five year old son, who would have belonged to his mother's clan.

Clark also attempted to assign a 'moiety identity' to the clans on the basis that the 'clan head's' moiety affiliation was known (1990, passim). As such, Clark suggested that various localised patriclans belonged to one matrimoiety or another-an obvious misunderstanding of the distinction between social groups and territorial groups, and contrary to Howitt's (1996 [1904], p. 44) information that these two types of organisation, while found together in aggregate at a regional level, were not conterminous at the local level in matrimoiety systems. In attempting to assign the matrimoiety identity of the male head of a local group to the entire local group (all of whom would have belonged to the moiety of their mother(s), except the clan head's actual and fictive bothers), Clark conflated distinct aspects of territorial and social organisation. This is not to say that territoriality and social organisation can be understood in isolation from each other, but rather that such conflations elide the crucial co-constituting duality of organisational structures, and in this case produce a matricentric portrait of descent. Interestingly, Clark documented a related error in one of the early sources: the work of Mathews (1904). In this particular case, it was not a matter of assigning matrimoiety identities to patrifilial estate groups in toto, but rather that Mathews tried to affix locations to a series of non-localised social matriclans (or matriphratries) that belonged to the Krokitch/Gammutch matrimoieties of the Wimmera and Mallee regions. Clark (1990, p. 362) stated that he could not resolve the status of this series of 'clans', as they lacked the usual 'clan' suffixes and he was unable to find any locational data for them. What is obvious here is that Mathews, in an inversion of the error made by Clark, tried to fix social units to particular tracts of local country, and Clark, presumably due to his misreading of local organisation in this area, was left unsure as to what to say in relation to Mathews's data. I would argue that there is no locational data for these groups because they are non-local matriclans.

I hasten to add that these issues do not invalidate Clark's 1990 atlas; it remains a very useful source for working though reconstructions of territory and language in the study area (indeed, alongside Dawson 
and Howitt, it is one of the first texts I turn to in these matters). Clark's extensive bibliographic section remains one of the most useful research resources available for those interested in the Aboriginal history of central and western Victoria. However, these anthropological errors in the work do require noting, especially since Clark's work is widely read by archaeologists, historians and other researchers, and is also well known in the Aboriginal communities of western Victoria.

\section{Confusion in the Early Sources}

While I do not intend to speculate on the precise causes of the anthropological oversights in Clark's work, it is fair to say that the two key ethnohistoric works by Dawson (1881) and Howitt (1996 [1904]) that I have focused on in my sketch of the original systems are themselves confusing and inconsistent. Dawson, in particular, had a range of apparently irresolvable data in his portrait of the original peoples, and I will focus on a few resolvable examples that relate to descent and organisation. Dawson gave an account of the operation of succession to vacant land at the level of the 'family', which I would argue is an instance of a patrifilial estate group. Dawson $(1881$, p. 7) wrote:

Should a family die out without leaving 'flesh relatives' of any degree, the chief divides the land among the contiguous families after a lapse of one year from the death of the last survivor ... If however there are several claimants, with equal rights to the territory, the chief at once gives an equal share, irrespective of sex or age. (emphasis added)

Dawson presented a somewhat unorthodox understanding of landholding in this quotation. The idea that land is apportioned to people irrespective of sex' goes against the view presented thus far that local groups in southwest Victoria were ideally patrifilial in the transmission of landholdings. However, we need to take account of the operation of two relevant social norms recorded by him:

Levirate-where the brother, or nearest male relative, of the deceased estate group owner is obliged to marry his deceased man's wife. (Dawson, 1881, p. 27)

1. Viri-patrilocal residence-whereby the female members of the estate group, upon marriage, would move off their father's estate to that of their husband and/or husband's father. (Dawson, 1881, pp. 27, 31) 
In considering these norms, we can see that the radically cognatic aspect of the system of succession, as outlined by Dawson, is in fact countered by the underlying patriarchy. In operation, this would essentially reproduce the patrifilial bias that is the norm in local organisation in this region. Due to levirate and viri-patrilocal residence (and the supposedly uniform institution of marriage), the only people left to inherit and inhabit an estate-contested or otherwise-are males.

However, it could still be the case that some women remained in their father's local country after marriage. In these cases, the husband would come to live with the wife on his father-in-law's land. Although the ideal of the viri-patrilocal residence was widespread in Aboriginal Australia, anthropologists working with groups in other parts of Australia found that in practice there was a high incidence of young male affines residing with their in-laws (for an overview, see Hiatt 1966, pp. 81-9; 1996, pp. 23-6; Peterson 1974, 1983). It is possible that this would also have been the case in western Victoria. This means that some women continued to reside in their father's band, which was residentially and economically based on their own patrifilial estate, rather than moving to their husband's father's land and band. While Dawson (1881, p. 7) did not record this type of event, this could have been the source of his 'irrespective of sex or age' comment. However, even if viri-patrilocal residence did operate in western Victoria, it in no way points to a primarily matrilineal landholding system at the local level.

While Howitt's work is clear about the relationship between social and territorial organisation in the study area, some of Howitt's comments, if read in isolation, can be confusing. Howitt (1996 [1904], p. 44) labelled local organisation in an unorthodox manner, using distinct terms for local groups in matrimoiety and patrimoiety societies:

Horde, the primary geographical division of a tribe having female descent ... Clan, the primary geographical division of a tribe with descent in the male line.

It would be easy to read these definitions in isolation and assume that the descent that Howitt spoke of related to the local organisation of 'hordes' and 'clans'. However, it is evident that Howitt was referring to descent as it related to the overarching social organisation that obtains across these hordes and clans. Speaking specifically of matrimoiety societies, Howitt (1996 [1904], p. 43) wrote: 
The son is of the father's horde and tribe, but of the mother's totem and class; of the local division to which the father belongs, but of the mother's social division. (emphasis added)

These two short examples point to the necessity of rereading early sources in some detail, and to work through the conceptual frames that early amateur ethnographers put in place in order to discern the proper intent of their data. This is not merely a matter of correction of the ethnohistoric and later reconstructive record; rather, it is important to note that these early records and the range of reconstructions that flow from them have the potential to have a wideranging impact in current social and political contexts.

\section{Conclusion}

Aboriginal people of the study area have maintained vibrant local oral traditions related to their society, culture and history of survival in the face of ruthless colonial forces (Aboriginal History Programme 1988; Critchett 1998). It is also true that these communities have had a keen interest in the published ethnohistoric and reconstructive accounts of their ancestral groups. The works of Dawson (1881) and Howitt (1996 [1904]) have been reissued as facsimiles in recent decades and, along with Tindale (1974) and Clark (1990), are commonly found in Aboriginal households across the region. While still driven by oral histories, Indigenous knowledge systems are inevitably being influenced by the written record. Moreover, within the last generation, there has been much legal and policy change around cultural heritage and land justice issues, and these texts have all fed into the Aboriginal archaeological, historical, anthropological, legal and governmental views on matters such as territorial boundaries and the composition of traditional owner groups. This has occasioned some contestation over the appropriate labels used to identify Aboriginal groups, and differences of opinion on what 'boundaries' are most appropriately associated with particular groups (which is understandable given the range of linguistic, social and territorial 'boundaries' in the written record).

My concern here is that misreading and misapprehension of original organisational structures makes the task of properly tracking the continuities and changes across the years, and connecting present-day Aboriginal communities to their ancestral structures, much more difficult. (This task is of crucial importance in cultural heritage and native title 
processes.) The view that 'matrilineality' was the dominant organising principal leads to the suggestion that perhaps less change has taken place than might otherwise have been noted. While in the past, many accounts were overly focused on the 'destruction' of Aboriginal societies (e.g. Rowley 1970), in the present, perhaps we run the risk of continuities being stressed at the expense of the raft of adaptive changes that have occured in order for the Aboriginal communities of the study area to survive-for survive they have. The understandable association between the bias towards matrifocal domestic patterns today and 'matrilineal clans' in the past might have the unintended consequence of eliding the complex duality of the territorial and social organisation of the original groups and underplaying the extent to which Aboriginal groups have rebounded from the violent expropriation of their land at the local level.

\section{References}

Aboriginal History Programme 1988, Memories last forever, Abbottsford: Aboriginal History Programme.

Blake, B \& Reid, J 1998, 'Clasifying Victorian languages', in B Blake (ed.), Wathurung and the Colac language of southern Victoria, Canberra: Pacific Linguistics.

Clark, ID 1990, Aboriginal languages and clans: an historical atlas of western and central Victoria, 1800-1900, Melbourne: Monash University.

Clark, ID 1995, Scars in the landscape: a register of massacre sites in western Victoria 1803-1859, Canberra: Aboriginal Studies Press.

Clark, ID (ed.) 1998a, The journals of George Augustus Robinson, vol. 1, Melbourne: Heritage Matters.

Clark, ID (ed.) 1998b, The journals of George Augustus Robinson, vol. 3, Melbourne: Heritage Matters.

Clark, ID (ed.) 1998c, The journals of George Augustus Robinson, vol. 4, Melbourne: Heritage Matters.

Clark, ID 2000, The papers of George Augustus Robinson. Vol. 2. Aboriginal vocabularies: south east Australia, 1839-1852, Clarendon: Heritage Matters. 
Clark, ID 2006, 'Land succession and fission in nineteenth-century western Victoria: the case of Knenknenwurrung', The Australian Journal of Anthropology, 17(1), pp. 1-14. doi.org/10.1111/j.1835-9310.2006. tb00044.x.

Coutts, PJF 1981, Readings in Victorian prehistory. Vol. 2. The Victorian Aboriginals 1800 to 1860, Victoria: Ministry for Conservation.

Critchett, J 1982, 'A closer look at cultural contact: some evidence from "Yambuk", Western Victoria', Aboriginal History, 8(1), pp. 12-20.

Critchett, J 1990, A 'distant field of murder': Western District frontiers 1834-1848, Melbourne: Melbourne University Press.

Critchett, J 1992, Our land till we die: a history of the Framlingham Aborigines, Warrnambool: Deakin University Press.

Critchett, J 1998, Untold stories: memories and lives of Victorian Kooris, Melbourne: Melbourne University Press.

Dawson, J 1881, The Australian Aborigines: the languages and customs of several tribes in the Western District of Victoria, Australia, Melbourne: Robertson.

Dawson, J n.d., Scrapbook, MS 11619: La Trobe Library, Melbourne.

Hiatt, L 1966, 'The lost horde', Oceania, 37, pp. 81-92. doi.org/10.1002/ j.1834-4461.1966.tb01789.x.

Hiatt, L 1996 Arguments about Aborigines: Australia and the evolution of social anthropology, Cambridge: Cambridge University Press

Howitt, AW 1884, 'On some Australian beliefs', Journal of the Anthropological Institute of Great Britain and Ireland, 13, pp. 185-98. doi.org/10.2307/2841724.

Howitt, AW 1886, 'On Australian medicine men', Journal of the Anthropological Institute of Great Britain and Ireland, 16, pp. 23-59. doi.org/10.2307/2841737.

Howitt, AW 1888, 'Further notes on the Australian class systems', Journal of the Anthropological Institute of Great Britain and Ireland, 18, pp. 31-70. doi.org/10.2307/2842513. 
Howitt, AW 1996 [1904], The native tribes of south-east Australia, Canberra: Aboriginal Studies Press.

Keen, I 1988, 'Introduction', in I Keen (ed.), Being black: Aboriginal cultures in 'settled' Australia, Canberra: Aboriginal Studies Press, pp. 1-26.

Lévi-Strauss, C 1979 [1963], Structural anthropology, Middlesex: Peregrine Books.

Lydon, J 2009, Fantastic Dreaming: the archaeology of an Australian Aboriginal mission, Lanham MD: AltaMira Press.

Madden, R 2006, 'Victoria’s Western District', in P Beilharz \& T Hogan (eds), Sociology: place, time and division, South Melbourne: Oxford University Press, pp. 99-103.

Madden, R 2010, 'James's Dawson's scrapbook: advocacy and antipathy in colonial western Victoria', La Trobe Journal, 85(May), pp. 55-69.

Mathew, J 1911, 'The origin, distribution, and social organisation of the inhabitants of Victoria before the advent of Europeans', The Victorian Historical Magazine, 1(3), pp. 79-89.

Mathews, RH 1904, 'Ethnological notes on the Aboriginal tribes of New South Wales and Victoria: part 1', Journal of the Royal Society of New South Wales, 38, pp. 203-381.

Peterson, N 1974, 'The importance of women in determining the composition of residential groups in Aboriginal Australia', in F Gale (ed.), Women's role in Aboriginal Australia, Canberra: Australian Institute of Aboriginal Studies, pp. 9-16.

Peterson, N 1983, 'Rights, residence and process in Australian territorial organization', in N Peterson and M Langton (eds), Aborigines, land and land rights, Canberra: Australian Institute of Aboriginal Studies, pp. 134-45.

Rowley, C 1970, The destruction of Aboriginal society, Canberra: Australian National University Press.

Smyth, RB 1876, The Aborigines of Victoria, Melbourne: John Curry, O’Neil. 
4. THE SOURCES OF CONFUSION OVER SOCIAL AND TERRITORIAL ORGANISATION

Stewart, D 1880, Aborigines of the Buandik tribe of the south east of South Australia, Introduction, South Australian Museum Archives AA 307/1.

Sutton, P 2003, Native title in Australia: an ethnographic perspective, Cambridge: Cambridge University Press. doi.org/10.1017/CBO 9780511481635.

Swain, T 1991, 'The mother Earth conspiracy: an Australian episode', Numen, 38, pp. 3-26. doi.org/10.2307/3270002.

Tindale, NB 1974, Aboriginal tribes of Australia, Berkeley: University of California Press. 
This text is taken from Skin, Kin and Clan: The dynamics of social categories in Indigenous Australia, edited by Patrick McConvell, Piers Kelly and Sébastien Lacrampe, published 2018 by ANU Press, The Australian National University, Canberra, Australia.

doi.org/10.22459/SKC.04.2018.04 